\title{
Group Enterprise Competitive Strategy research
}

\author{
Zhiqiang Feng ${ }^{1, a}$, Zhen $\mathrm{TaO}^{2, \mathrm{~b}}$ \\ ${ }^{1}$ Henan Industry \& Trade Vocational College,Zhengzhou,450012,China \\ ${ }^{2}$ Henan People's Broadcasting Station,Zhengzhou,450003,China \\ aemail:fzq2007@aliyun.com, ${ }^{\mathrm{b}}$ email:amytaomimi@126.com
}

Keyword: Enterprise Strategic; Value; Competitive Advantage; Core Competitiveness

\begin{abstract}
This article obtains from the group enterprise different characteristics research, analysis of the value of the group enterprise form, through to the group enterprise competitive advantages and core competitiveness of factor analysis, this paper discusses the group enterprise how to form core competitiveness, discussed group enterprise competitiveness strategy and tactics.
\end{abstract}

\section{Introduction}

Most group enterprise set up time is relatively late, the scale of the enterprise is moderate, most businesses in the sunrise industry. Industry development environment, to the enterprise created a larger profits space, rich profit for the enterprise to speed up the pace of development, adopting the new system as soon as possible, new mechanism provides the abundant economic basis. Fully market competition has made the inefficient enterprises gradually eliminated, group enterprise in this specific environment was born.

Group of enterprises' competitive strategy It is thought that there are three: cost leadership, differentiation strategy, focused strategy. In competition in the market potential, manifests itself as a leading strategy, challenges, strategy, follow the strategy, strategy. In the development of the market life cycle, performance for the sun, mature market strategy, market strategy recession marketing strategies. Select a group of competitive development direction is important.

\section{Problem of enterprises' competitive strategy}

Group the influence of the enterprise value creation activities mainly through the way such as organization, strategy, business and finance. A country's economic development to a certain level will appear a number of big enterprise, big group. Group enterprise can produce higher by group headquarters is value creation function. See Figure 1. Classification of enterprise competitive strategy.

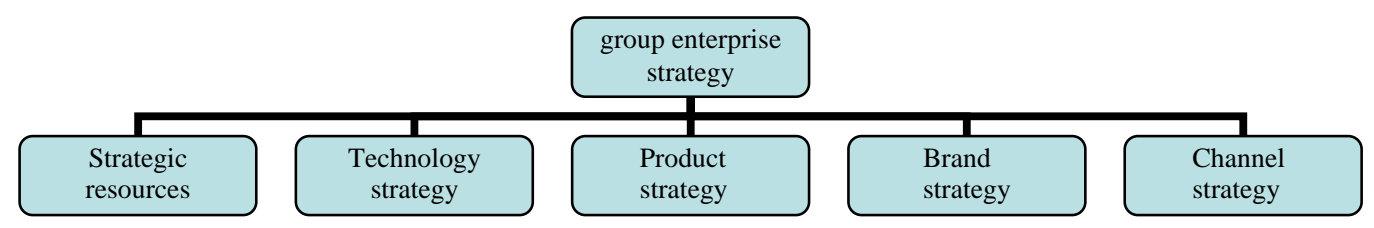

Fig.1. Type of Enterprise competitive strategy

Group enterprise to create value. Group enterprise's influence on the value creation activities mainly through the way such as organization, strategy, business and finance. Take appropriate organizational structure. By changing the allocation of corporate power structure, company organization relationship, function of organization setting and equipped with powerful functions of human resources leadership, through the output management to influence and control of the operation and management of subordinate business unit. The first is a holding company structure; the second is centralized, according to the functional departments of a units structure; Three is more department or branch unit structure. Look from the development trend, the enterprise organization is from the vertical structure of the pyramid to parallel network structure, management procedure from the order is changed to parallel transition, organic and flat organizational structure, and 
management "bandwidth" to increase. ChunLan, Haier, ChangHong, Made take department all has obtained the good effect.

To create value-added business space. By its subordinate business unit and business unit between associated horizontal and vertical single effect influences, or by changing the combination of industry structure, business process restructuring, to redefine the business (such as joint or separate business), and help provide continuous operation of the management, achieve business synergies. Group enterprise effort by business management to realize the connections between economies of scale. Pay special attention to the financial control the lifeblood. Financial control is one of the most important form of corporate control, is an important part of the group headquarters control member enterprises.

Enterprise core competitive ability is a certain system framework, knowledge, based on unique technology enterprises have accumulated a competition ability. Core competitive ability is the enterprise competitiveness only a part, is in the core status, influence global competitiveness. Core competitive ability is the competitive advantage, is a kind of comparative advantage. Comparative advantage is mainly refers to a country or a region's resource endowment advantage, core competence emphasized the combination of the comparative advantage and competitive advantage. Core competence is the nature of enterprise knowledge capital. Include: human capital, technology capital, organizational capital, customer capital and social capital. Enterprise core competitive ability of innovation, technological innovation is an important approach to improve enterprise's core competitive ability; Management innovation is an important means of strengthening enterprise core competitive ability; System innovation is the support enterprise core competitive ability important guarantee.

\section{Group Enterprise Innovation}

Management innovation is an important means of strengthening enterprise core competitive ability. Technology and management is the modern enterprise development of the two wheels. The real source of the enterprise core competitive ability lies in management skills. Management of technology and production skills can be transformed into enterprise's ability to adapt to change quickly. Man is the decisive factor in the development of social productive forces, is the enterprise core competitive ability to the creators and maintainers.

System innovation is the enterprise core competitive ability important guarantee. The development of the enterprise core competitive ability and technological innovation and management innovation, system by influencing the availability of information, resources, shaping the power, and establishing trading rules to influence development of enterprise and industry. The influence of different institutional environment to the enterprise core competitive ability is different. System related to financial, employment, etc, making the Japanese companies have different management and organizational characteristics. Germany, leading in the field of chemical industry and the United States on the computer, the success of the software industry has a great connection with their education system. Venture capital market, is the emerging industry, such as biological industry, the main reasons for the rapid development of this system promotes the rapid growth of small businesses, expand the market. In this respect, Europe, Japan enterprises cannot be compared with the United States.

Through market segmentation, resource restructuring and process reengineering, etc way to update the management strategy. Establishing the learning organization, actively absorb modern management thinking, forming the advocation innovation enterprise culture, promote the management innovation, to strengthen the enterprise core competitive ability. Perfect financial market, to promote science and technology, industry, capital - market linkage, and development of risk investment mechanism, financing channels, expanding industry will directly affect the enterprise technology innovation, restricts the promotion enterprise's core competitive ability.

Improve the system of human resource development and management, the mechanism of talented people and develop people. The intellectual property system can not only stimulate innovation. Multinational companies implement localization of patent strategy, china must strengthen the 
enterprise independent innovation, enterprise development to circumvent foreign patent protection barriers, cultivate their own core competitive ability, create a fair and just competition for the enterprise external environment.

\section{Group Enterprise Strategy}

Group enterprises to accumulate a large amount of capital reserves, enterprise labor management and technical quality is higher and higher. As the market increasingly competitive, many industry demand for high value-added products is more and more big. China has the resources advantage, technical superiority, product advantage, brand advantage, channels and investment advantages. People can use Tab.1 analysis on Competitive Strategy Fig.2. effects of competitive strategy of an enterprise competition strategy selection, as shown in figure Tab.1and Fig.2. Selection Model of Group enterprises' competitive strategy.

Industry market prospect

unappealing Moderately attractive Strong attraction Rate of return on investments

\begin{tabular}{|l|c|c|c|}
\cline { 2 - 4 } Weak & $\begin{array}{c}\text { Not to } \\
\text { invest }\end{array}$ & $\begin{array}{c}\text { In stages to } \\
\text { retreat }\end{array}$ & $\begin{array}{c}\text { Accelerated } \\
\text { development/ } \\
\text { Retreat }\end{array}$ \\
\cline { 2 - 4 } Siddle & $\begin{array}{c}\text { In stages } \\
\text { to retreat }\end{array}$ & $\begin{array}{c}\text { Pay close } \\
\text { attention }\end{array}$ & Reinforcing \\
\cline { 2 - 4 } Strong & $\begin{array}{c}\text { Source of } \\
\text { funding }\end{array}$ & Development & Lead \\
\hline \multicolumn{2}{|c}{} & \multicolumn{2}{|c}{} \\
\hline
\end{tabular}

Business unit's ability to compete

Tab.1.Analysis on Competitive Strategy

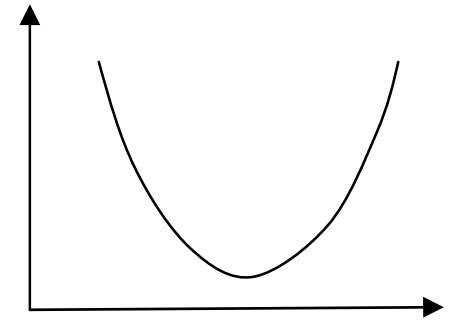

Market share

Fig.2.Effects of competitive strategy

The group of enterprises' competitive strategy in terms of branding, technology, marketing, information, logistics, funding and other enterprises on the elements of the value chain, substantial changes in the current competition between enterprises, enterprise and Enterprise Competition is a competition for its value chain system or the value chain, in different companies in the life cycle, select the enterprise competitive strategy. As shown in table 2.

Industry life cycle

Investment period Long term Maturity Recession

\section{Domination \\ Stronger \\ Favourable \\ Defense \\ Weak}

Enterprise's competitive footing

Tab.2. Competition strategies of the different stages of life cycle

\section{Conclusion}

Advantages of China's access to resources, technology, product, brand advantages, channel and investment advantages. Implementation and control of the group of enterprises' competitive strategy : In the area near high-end strategic mineral resources reserves set up its own manufacturing base, established at overseas bases and foothold.Leverage investments to drive sales, acquisition of world-class research and development institutions, foreign high - tech brand, in research and development institutions abroad, launch products in the world.The acquisition of failed or poor management company in foreign markets and occupied the regional market. Gradually expand the brand's share of international markets, in order to achieve the purpose of promoting the brand in the domestic market value. 


\section{Acknowledgement}

This article is in henan province enterprise group strategy research project (2010-026) and henan industry and trade vocational college research project (2012-12).

\section{References}

[1]Michael.PorterStrategic Management [M]Shanghai Sanlian Bookstore Publishing House, 1988

[2] Ronald Coase.The Economist [M]Shanghai Sanlian Bookstore, 1994

[3] H. Fayol.Enterprise Management [M]Beijing China Social Sciences Press, 1982

[4] L. Kate's.Modern Enterprise Strategy [M] Beijing China Commercial Press, 1994

[5] Ansoff.Strategy [M] Beijing's Tsinghua University Press, 1997

[6] So, He.Classic Business Ideas [M] Haikou Hainan Publishing House, 2005

[7] Kazuo Inamori.On Business [M] Haikou Hainan Publishing House, 2006

[8]Zhiqiang Feng.The Small And Medium-Sized Enterprise Groups Strategic Management [M] Beijing China Broadcasting And Television Press, 2005

[9]Zhiqiang Feng.China Economic Theory[M] Beijing China Economic Publishing House, 2006

[10]RongpingChen.The Granddaddy Of Strategic Management[M] Shijiazhuang Hebei University Press,2005 